\title{
EFFECT OF CALCIUM AND BORON AS FOLIAR SPRAY ON "LE CONTE" PEAR TREES PRODUCTIVITY
}

\author{
H.M. Abo Ogiela( ${ }^{(1)}$, S.M. Hussien ${ }^{(1)}$, E. A. M. Osman ${ }^{(2)}$ \\ and A. E. A. Shiref ${ }^{(2)}$ \\ ${ }^{(1)}$ Hort. Res. Inst., ${ }^{(2)}$ Soils, Water and Environ. Res. \\ Inst., Agric. Res. Centre, Giza, Egypt.
}

Received: May 29, 2019

Accepted: Jul. 22, 2019

\begin{abstract}
This study was carried out during 2016 and 2017 seasons on twenty years old "Le Conte" pear trees budded on Pyrus communis rootstock, grown at ElKanater Horticultural Research Station to investigate the effect of foliar application of $\mathrm{Ca}(\mathrm{NO} 3)^{2}$ (1 and $2 \%$ ) and borax (100 and 200 ppm) as individual or in combined on yield, leaf mineral content and fruit characteristics. The results obtained that, the highest fruit length, size, and diameter as well as fruit weight $(\mathrm{g})$, fruit yield/ tree $(\mathrm{kg})$ and fruit yield as ton/fed. were recorded when pear tree was sprayed with 1 or $2 \%$ calcium nitrate + 100 or 200 ppm borax compared with both calcium and borax alone. Fruit firmness and acidity were increased by foliar spray of combined treatment calcium 100 or 200 ppm borax +1 or $2 \% \mathrm{Ca}\left(\mathrm{NO}_{3}\right)^{2}$ compared to control. Spraying 1 or $2 \% \mathrm{Ca}(\mathrm{NO} 3)^{2}$ alone gave the highest significant value of $N \%$ for pear leaves meanwhile $P \%$ was improved significantly using $200 \mathrm{ppm}$ borax $+2 \% \mathrm{Ca}\left(\mathrm{NO}_{3}\right)^{2}$. Also, $\mathrm{K}, \mathrm{Ca}$ and $\mathrm{Mg} \%$ were increased significantly with spraying $200 \mathrm{ppm}$ borax $+2 \% \mathrm{Ca}\left(\mathrm{NO}_{3}\right)^{2}$. In most cases, leaf $\mathrm{Fe}$ and $\mathrm{Zn}$ contents were increased significantly by combined treatment of 100 or 200 ppm borax + $2 \% \mathrm{Ca}\left(\mathrm{NO}_{3}\right)^{2}$ or $100 \mathrm{ppm}$ borax alone .
\end{abstract}

Kew words: Pear trees, Le-conte, calcium, boron, yield and fruit quality

\section{INTRODUCTION}

Pear (Pyrus communis L.) is one of the favorite fruits of temperate zone and considered the third highest production of deciduous fruits, the fourth highest production among all fruits in its global distribution and one of the most vital deciduous fruits in Egypt. 'Le Conte' pear resulted as a hybrid between Pyrus communis $\mathrm{L}$. $x$ Pyrus serotina $\mathrm{L}$., is the main pear cultivar grown in Egypt. The total cultivated area for pear fruits were 3741 hectares with total production estimated to 48817 ton (FAO, 2016). Pear orchards productivity differs in Egypt from year to year and location to another. This might be attributed to limited ovules viability and stigma receptivity, deprived pollen germinability, ovule abortion, extreme flower abscission and low fruit set (Goldwin, 1986). Since consumers prefer large pears, fruit size becomes a very important marketing parameter and the economic benefits of treatments capable of improving average fruit size are considered of high potential.

Calcium is a nutritional element that differs from others by being imported into fleshy fruit only in small quantities, much less than into leaves. Ca uptake and distribution in plant is affected by internal water movement and relative $\mathrm{Ca}$ rate seems to be used along the transport pathway (Saure, 2005). Although it is sufficiently available in the soil, localized Ca deficiency may become a problem in several fruit crops, with the large economic losses risk. Some authors suggested a competition for $\mathrm{Ca}$ between low-transpiring fruit and vigorously growing, highly transpiring leafy shoots (Montanaro et al., 2006). Calcium promotes early root formation 
and growth, improves general plant vigor, stiffness of stalks and improves fruit integrity. Calcium influences the uptake of other nutrients such as phosphorous, manganese, iron, zinc and boron (Polevoiy, 1989). Calcium is considered one of the most important element for fruit crops in arid and semiarid regions, since it is required for cell elongation and cell division (Rizzi and Abruzzese, 1990). The foliar application of "Kelsey" plum with $\mathrm{Ca}\left(\mathrm{NO}_{3}\right)^{2}$ greatly improved the fruit set, nitrogen and calcium leaf content, retained fruits, fruit weight and tree yield, over control (Abdel Hafeez et al., 2010). Calcium plays a vital role in regulating the metabolism in apple fruit, maintaining adequate concentration for fruit firmness and delaying fruit ripening (Demuth and Sundrud, 2012). The beneficial effect of calcium in increasing fruit set may be due to the high efficiency of photosynthesis and these chemicals are also associated with hormone metabolism, which promotes synthesis of auxins, essential for fruit set and growth (Kazemi, 2014).

Boron (B) is considered an essential micronutrient that is associated with both vegetative growth and plant reproductive development, and it has been involved in the antioxidant systems of vascularized plants. It is also involved in changes in concentration and metabolism of phenolic compounds in vascular plants, in response to its excess or deficiency (Dahajipour et al., 2011; Moalermi et al., 2012). The $B$ requirements have also been reported to be greater in reproductive than vegetative structures due to it is involved in several processes, such as flowering, pollen tube growth, and fruit ripening (Herrera- Rodrlguez et al., 2010). Foliar spraying of $B$ to crops during the reproductive season, more effective than soil applications, this method has the advantages of requiring lower application rates, a more uniform distribution and more rapid plant responses to application of nutrients (Saadati et al., 2013). foliar B applications are included in the agronomical management during the blueberry reproductive season to ensure a good fruit set and increased yield, and the applications are combined with other nutrients, such as calcium (Ca) (Stückrath et al., 2008). Wimmer and Eichert, (2012) indicated that B facilitates the transport of sugars produced by the formation of B-sugar complexes or the increased leaf photosynthesis rate caused by the role of $B$ on physiological processes. In addition to water, fruits are rich in sugars, two constituents for which $B$ plays a key role in translocation. The role of $B$ in the reduction of the oxidative stress that related to the increase in reactive oxygen species (ROS) which has been reported in the nuts of species such as European hazelnut (Mishra et al., 2010). Therefore, the present investigation was carried out to investigate the effect of the most promising chemical treatments on improving fruit set, yield and fruit quality of Le Conte pear tree by using different concentrations of boron and calcium nitrate as a foliar application.

\section{MATERIALS AND METHODS}

The present investigation was carried out during two successive seasons, 2016 and 2017, on twenty years old "Le Conte" pear trees budded on Pyrus communis rootstock planted at $5 \times 5 \mathrm{~m}$ apart and grown on clay loam soil under surface irrigation system, at El-Kanater Horticultural Research Station to study the effect of $\mathrm{Ca}\left(\mathrm{NO}_{3}\right)^{2}$ and borax (source of boron) as a foliar application on yield, leaf mineral content and fruit quality of pear trees. The trees were in normal growth, uniform in vigor and received normal fertilization and agricultural practices as scheduled in the commercial 
orchard. Physical and chemical analyses

of the experimental soil are illustrated in

Table (1): Some physical and chemical properties for the experiment site

\begin{tabular}{|c|c|c|c|c|c|c|c|c|c|c|c|c|}
\hline \multirow[t]{2}{*}{ Characters } & \multicolumn{3}{|c|}{$\begin{array}{c}\text { Particle size } \\
\text { distribution (\%) }\end{array}$} & \multirow[t]{2}{*}{$\begin{array}{l}\text { Textural } \\
\text { class }\end{array}$} & \multirow[t]{2}{*}{ PH } & \multirow[t]{2}{*}{ Ec } & \multirow[t]{2}{*}{$\begin{array}{l}\text { O.M } \\
(\%)\end{array}$} & \multirow[t]{2}{*}{$\mathrm{CaCO}_{3}$} & \multicolumn{4}{|c|}{ Available (ppm) } \\
\hline & Sand & Silt & Clay & & & & & & $\mathbf{N}$ & $\mathbf{P}$ & $\mathbf{K}$ & B \\
\hline Value & 34.10 & 34.50 & 31.40 & Clay Loam & 7.65 & 0.95 & 1.65 & 2.12 & 37.22 & 8.24 & 314.25 & 0.75 \\
\hline
\end{tabular}

The treatments were arranged in the complete randomized block with five replicates for each treatments and one tree per each replicate ( 9 treatments $\times 5$ replicates $x$ one tree $=\mathbf{4 5}$ trees). The nine treatments were applied as follows

$\mathrm{T}_{1}$ - Control (untreated trees)

$\mathrm{T}_{2}$ - Spraying with $1 \% \mathrm{Ca}\left(\mathrm{NO}_{3}\right)^{2}$

$\mathrm{T}_{3}$ - Spraying with $2 \% \mathrm{Ca}\left(\mathrm{NO}_{3}\right)^{2}$

$\mathrm{T}_{4}$ - Spraying with $100 \mathrm{ppm}$ Borax

$\mathrm{T}_{5}$ - Spraying with $200 \mathrm{ppm}$ Borax

$\mathrm{T}_{6}$-Spraying with $1 \% \mathrm{Ca}\left(\mathrm{NO}_{3}\right)^{2}+100 \mathrm{ppm}$ Borax

$\mathrm{T}_{7}$ - Spraying with $2 \% \mathrm{Ca}\left(\mathrm{NO}_{3}\right)^{2}+100 \mathrm{ppm}$ Borax

$\mathrm{T}_{8}$ - Spraying with $1 \% \mathrm{Ca}\left(\mathrm{NO}_{3}\right)^{2}+200 \mathrm{ppm}$ Borax

$\mathrm{T}_{9}$ - Spraying with $2 \% \mathrm{Ca}\left(\mathrm{NO}_{3}\right)^{2}+200$ ppm Borax

The experimental trees were sprayed three times with the previous treatments at full bloom, which was at the beginning of March, a month later and then two months from the first spray in the two seasons

The effect of the previous treatments was studied by evaluating their effect on the following parameters:

\section{Fruit set percentage}

The total number of flowers at full bloom and the initial number of fruits at the end of blooming stage on the labeled limbs in all treatments were counted and recorded then the percentage of fruit set was calculated as the following equation according to Westwood (1978) as follows:

Fruit set (\%) =

Number of set fruitlets $\times 100$

Number of flowers at full bloom

\section{Fruit yield}

Tree yield was recorded at the time of harvesting; ( $2^{\text {nd }}$ week of August) and expressed as $\mathrm{kg} /$ tree and tons/fed. as well as number of fruits/tree for each treatment was counted.

\section{Fruit quality}

Samples of matured ten fruits at harvesting time from each replicate were collected and the following fruit characters were determined: fruit physical properties including the average values of fruit weight $(\mathrm{g})$, fruit size $\left(\mathrm{cm}^{3}\right)$, fruit length $(\mathrm{cm})$, fruit diameters $(\mathrm{cm})$ and fruit firmness $\left(\mathrm{lb} / \mathrm{inch}^{2}\right)$ was determined using pressure tester with $7 / 1 \quad 8$ inch plunger (Magness and Taylor 1925). In addition, fruit chemical properties were also estimated including TSS (\%) by hand refractometer, according to A.O.A.C (2000) and fruit juice titratable acidity (\%) according to Vogel (1968).

\section{Leaf and fruit mineral composition:}

Twenty leaves from the middle part of the shoots were selected randomly from each replicate (at the second week of August) and fruit samples were taken at harvest time to determine their content 
from N, P, K, Ca, Mg, Fe, Zn, Mn Cu and B according to Ryan et al., (1996). Determination was carried out on dry weight basis.

\section{Statistical analysis:}

All the obtained data during both seasons of study were tabulated and statistically analyzed using L.S.D test at $5 \%$ level for comparing between different treatment means according to Snedecor and Cochran (1969). All statistical analysis was performed using analysis of variance technique by means of "MSTAT" computer software package.

\section{RESULTS AND DISCUSSIONS Fruit set percent}

Results illustrated in Fig. 1 indicated that all treatments increased fruit set percentage significantly than the control especially the combined treatment $2 \%$ $\mathrm{Ca}\left(\mathrm{No}_{3}\right)^{2}+200$ ppm Borax which recorded the highest values followed by the treatment of $2 \% \mathrm{Ca}\left(\mathrm{No}_{3}\right)^{2}$ as foliar spray compared with the lowest values obtained by control. Calcium and boron together in the same solution had a positive effect on increasing fruit set \%. This may be due to the improving effect of such treatments on nutritional status which reflected on increasing fruit set and fruit retention. In this respect, Qin (1996) and Hassan (2000) reported that the improving fruit set could be explained as a result increasing pollen grains germination and pollen tube elongation due to boron treatments. Similar results were obtained by Mosa et al., (2015) who indicated that the calcium nitrate significantly increased fruit set, of "Le Conte" pear trees, over control. in the same line, Sarrwy et al., (2012) on date palm .

\section{Fruit yield}

Tabulated data in Table 2 reveal that the spraying calcium nitrate and boron together $\left(1\right.$ or $2 \% \mathrm{Ca}\left(\mathrm{NO}_{3}\right)^{2}+100$ or 200 ppm Borax gave the highest significant values of fruit weight $(g)$ fruit number, fruit yield/ tree $(\mathrm{kg})$ and fruit yield ton fed in both seasons. Meanwhile, sole foliar application of boron at two doses or control treatments led to significant decrease of such parameters in both ones. Increasing fruit yield due to boron and/or calcium spray may be attributed to their effect of increasing fruit set. Also, it may attribute to the role of boron in enhancing many metabolic processes such as sugars and carbohydrate transport (Mengel and Kirkby, 2001).

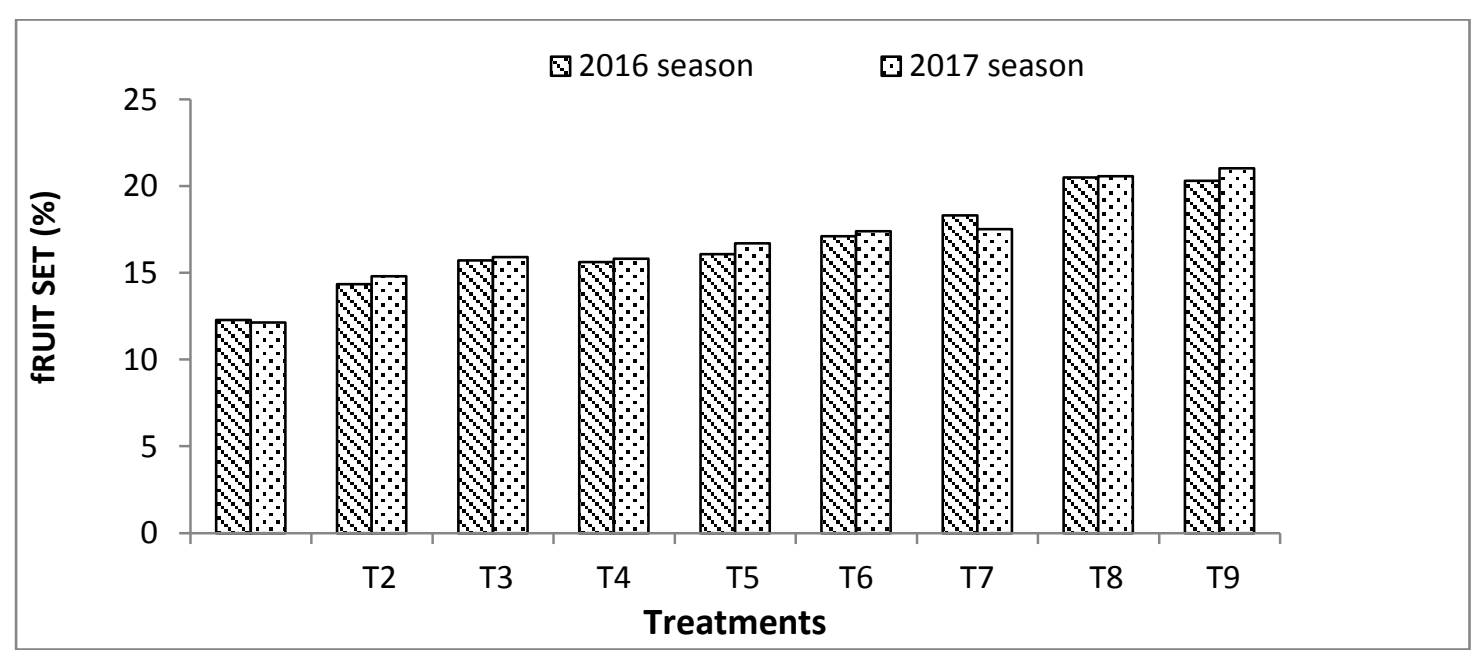




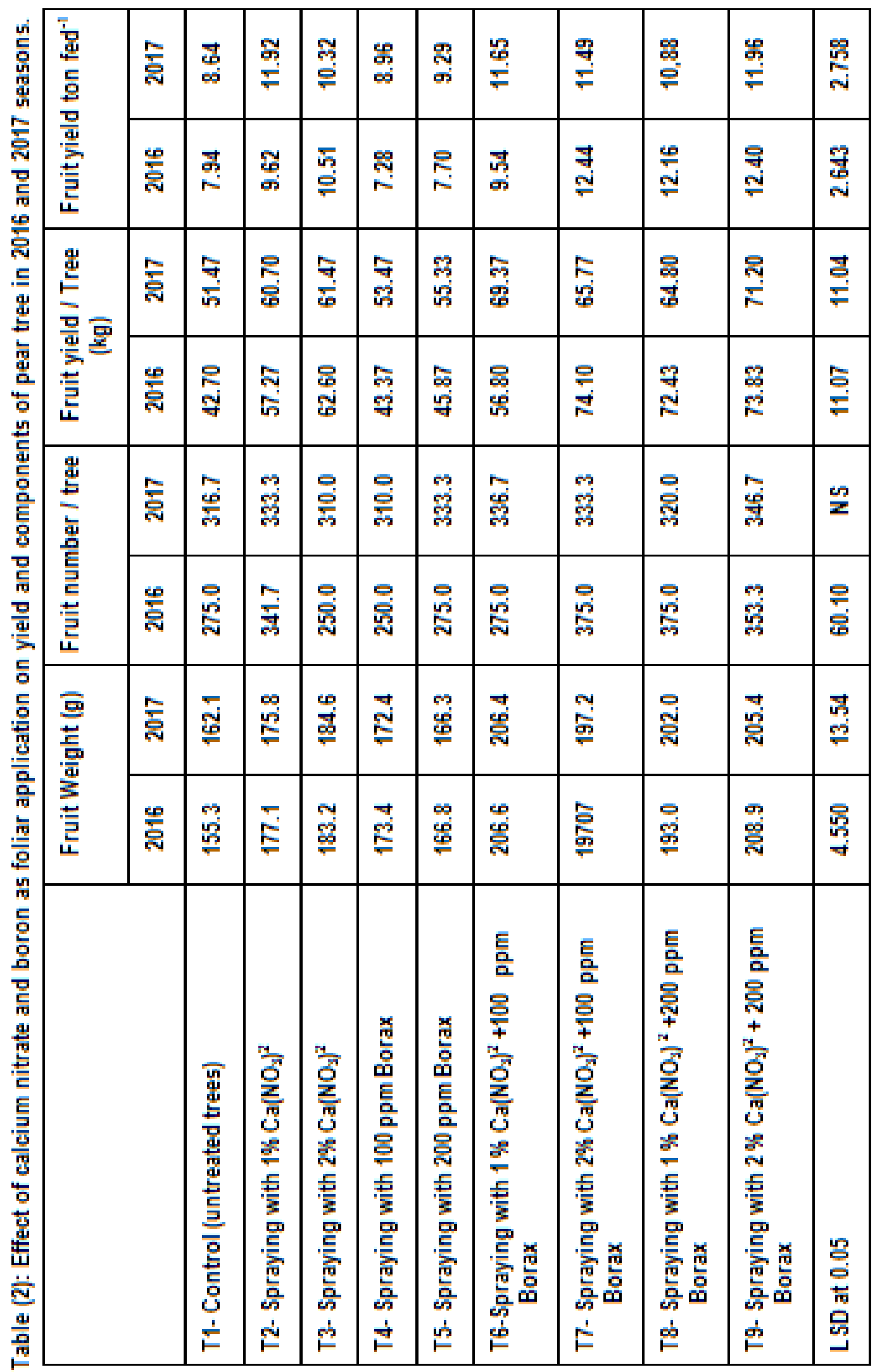

Fig. (1): Effect of calcium and boron as foliar application on fruit set $\%$ of pear trees in 
2016 and 2017 seasons.

\section{Fruit quality}

Data presented in Table 3 show that the highest significant values of fruit length, size, and diameter were recorded when pear tree, variety 'Le Conte' was sprayed with calcium nitrate and boron together $\left(1\right.$ or $2 \% \mathrm{Ca}\left(\mathrm{NO}_{3}\right)^{2}+100$ or 200 ppm Borax in both seasons. The same trend was obtained for fruit number/tree in the first season only. While, the lowest ones were noticed by control treatment or $200 \mathrm{ppm}$ Borax only in both seasons. Calcium is careful as one of the most essential nutrients determining the fruit quality, since it is required for cell elongation and division. Also, boron plays a vital role in many functions of the plant such as hormone movement, activate salt absorption, flowering and fruiting process and transport of sugars and carbohydrate (Khayyat et al., 2007). In this connection, Merwad et al., (2016); through studying the fruit quality, found that spaying $\mathrm{Ca}$. and $\mathrm{B}$ gave a high quality comparing with the control treatment. These results confirm with Stano et al., (2011) who found that foliar spray of mango trees with calcium nitrate and boric acid improved quality as well as physical and chemical mango fruit properties. Moreover, Khalifa et al., (2009) showed increases in the apples sizes (Malus domestica Borkh) from four- yearold trees sprayed with B (as $0.025,0.05$ and $0.1 \%$ boric acid) in two seasons and that may be attributed to the physiological role of $B$ to cell elongation and carbohydrate transport to reproductive tissues such as flowers and fruits. Concerning fruit firmness (Fig. 2) and acidity were improved significantly by foliar spray of calcium nitrate and boron together $\left(1\right.$ or $2 \% \mathrm{Ca}\left(\mathrm{NO}_{3}\right)^{2}+100$ or $200 \mathrm{ppm}$ Borax or alone compared with control treatment in both seasons. Moreover, TSS was increased significantly by spraying all treatment compared to $2 \% \mathrm{Ca}\left(\mathrm{NO}_{3}\right)^{2}+100 \mathrm{ppm}$ borax in the first season and 1 or $2 \% \mathrm{Ca}$ $\left(\mathrm{NO}_{3}\right)^{2}+100 \mathrm{ppm}$ Borax together and $1 \%$ $\mathrm{Ca}\left(\mathrm{NO}_{3}\right)^{2}$ alone in the second one. The beneficial effect of calcium could be attributed to the physiological role of calcium which plays a binding role in the complex polysaccharides and proteins forming the cell wall. Our results are in agreement with those recorded by Casero et al., (2004) and Asgharzade et al., (2012) who reported that the enhancement which occurred in fruit quality with foliar application of calcium could be attributed to the effect of calcium in enhancing and advancing flowering, maturity and the translocation of carbohydrates from leaves to fruits. Also, Mosa, et al., (2015) found that the foliar application of calcium nitrate at $1 \%$ had the highest beneficial effect to increase fruit set percentages, yield, fruit firmness and acidity in the fruit and to decrease fruit drop percentages of "Le Conte" pear trees compared with the control and the other treatments.

\section{Nutrition status \\ Leaf mineral contents ( $N, P, K, C a$ and $\mathrm{Mg}$ ) \\ Results in Table 4 reveal that spraying} 1 or $2 \% \mathrm{Ca}\left(\mathrm{NO}_{3}\right)^{2}$ alone gave the highest significant value of $\mathrm{N} \%$ for pear leaves in both seasons. As well, $\mathrm{P} \%$ was improved significantly using $2 \%$ Ca $\left(\mathrm{NO}_{3}\right)^{2}+200$ ppm borax in two seasons. Also, $\mathrm{K}, \mathrm{Ca}$ and $\mathrm{Mg}$ percentage were increased significantly with spraying $100 \mathrm{ppm}$ boron $+2 \% \mathrm{Ca} \mathrm{NO}_{3}$. On the other hand, the lowest significant values of all parameters were with control treatment in both seasons. Similar trend of the lowest uptakes was recorded for $\mathrm{K}$ and Ca content by foliar application of $2 \% \mathrm{Ca}$ (NO3)2 in the first season only. The obtained results are in harmony with those obtained by Sarrwy et al., (2012) on date palm, Mosa et al., (2015) on pear trees Hikal et al., (2017) on Navel orange, who stated that the foliar application of 


\begin{tabular}{|c|c|c|c|c|c|c|c|c|c|c|c|}
\hline \multirow{2}{*}{$\frac{\text { 를 }}{\text { 害 }}$} & 홀 & $\frac{B}{d}$ & $\frac{5}{8}$ & 点 & $\frac{\mathrm{g}}{3}$ & $\frac{3}{3}$ & 号 & 点 & 骂 & $\frac{8}{8}$ & 䍃 \\
\hline & 훌 & 骂 & 骂 & 옹 & 尽 & 总 & 总 & 总 & 옹 & 点 & $\frac{\bar{t}}{0}$ \\
\hline \multirow{2}{*}{$\begin{array}{l}\bar{E} \\
5 \\
5\end{array}$} & 를 & 룔 & 용 & $\mathrm{s}$ & $\mathrm{B}$ & 8 & 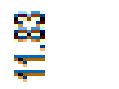 & 웅 & 8 & 8 & 홍 \\
\hline & 을 & 룰 & $\mathrm{s}$ & s & $\mathrm{g}$ & 8 & 预 & $\stackrel{5}{\rightleftarrows}$ & 율 & s & 8 \\
\hline \multirow{2}{*}{ 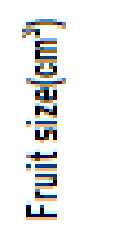 } & 흘 & 鸟 & $\overline{\bar{D}}$ & 8 & 올 & 올 & 욜 & 홀 & 횰 & 횰 & 욜 \\
\hline & 总 & 娄 & 홍 & $\mathbb{8}$ & 율 & 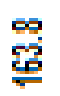 & ్ㅛㄹ & 営 & 룔 & 窎 & $\begin{array}{l}\text { 导 } \\
\text { vi }\end{array}$ \\
\hline \multirow{2}{*}{ 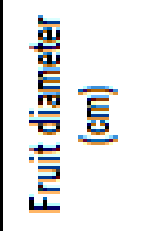 } & 돌 & 릉 & 害 & 言 & 曼 & 丞 & 홍 & 홍 & s & $\sum_{-1}$ & 웅 \\
\hline & 总 & $\underset{6}{8}$ & $\begin{array}{l}8 \\
8\end{array}$ & $\begin{array}{l}\mathrm{g} \\
\mathrm{g}\end{array}$ & 点 & 吱 & $\stackrel{5}{5}$ & 窎 & 马 & 윰 & 号 \\
\hline \multirow{2}{*}{ 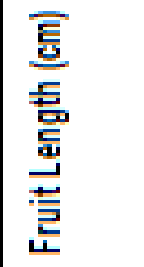 } & 홀 & 旁 & $\begin{array}{l}83 \\
8\end{array}$ & 8 & $\underset{\mathrm{E}}{\mathrm{s}}$ & 疍 & 寻 & 密 & 8 & 웋 & 올 \\
\hline & 훌 & $\stackrel{3}{3}$ & 罥 & 胥 & $\underline{s}$ & 点 & 壳 & 禺 & 售 & ్ㅗㅇ & 骂 \\
\hline \multicolumn{2}{|c|}{$\begin{array}{l}\text { 辜 } \\
\text { 害 } \\
\text { 总 }\end{array}$} & 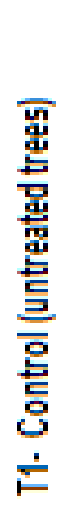 & 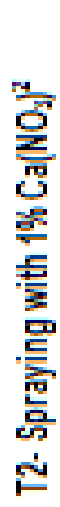 & 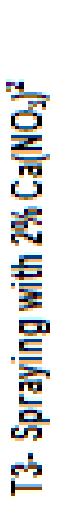 & 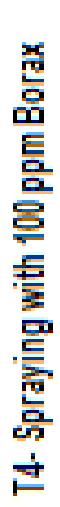 & 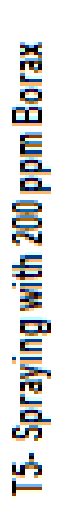 & 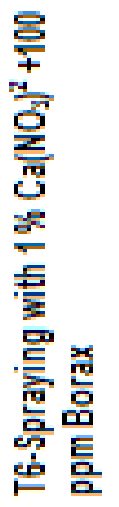 & 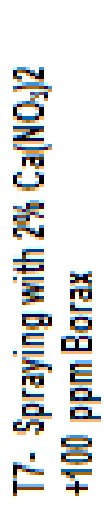 & 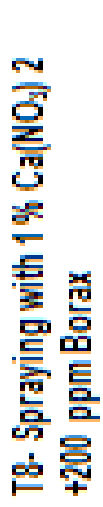 & 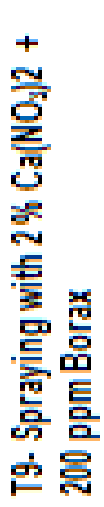 & $\begin{array}{l}\text { 명 } \\
\text { 䓫 } \\
\text { 뭄 }\end{array}$ \\
\hline
\end{tabular}

calcium nitrate significantly improved $\mathrm{N}$, $\mathrm{P}$. Ca and $\mathrm{Mg}$ content in the leaves over control treatment . 


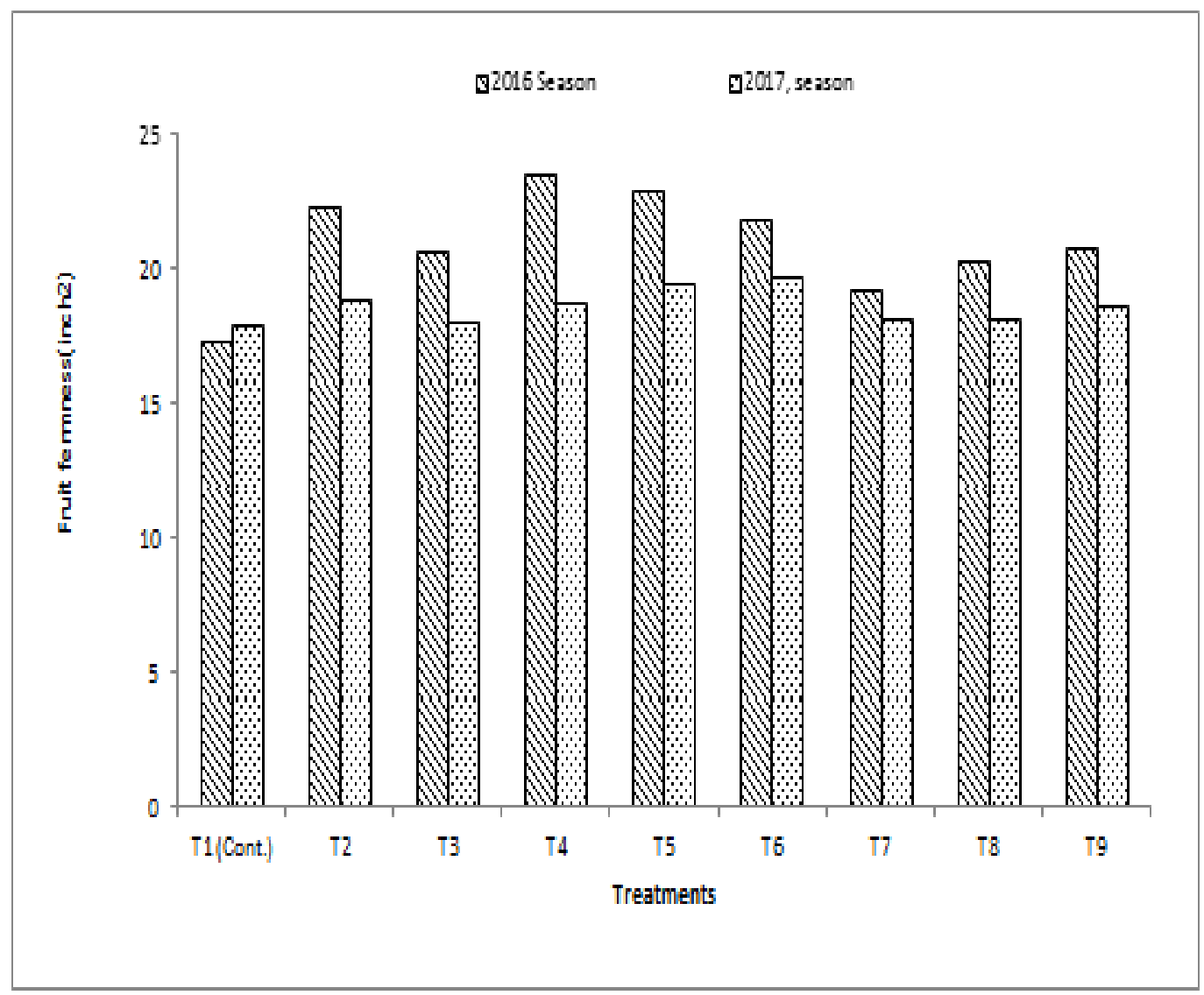

Fig. (2): Effect of calcium and boron as foliar application on fruit firmness. of pear fruits in 2016 and 2017 seasons. 


\begin{tabular}{|c|c|c|c|c|c|c|c|c|c|c|c|}
\hline 모 & 동 & ชั & 罟 & $\begin{array}{l}\text { 品 } \\
\text { 。 }\end{array}$ & $\begin{array}{l}\text { 芯 } \\
\text { ' }\end{array}$ & 点 & ஜु & $\begin{array}{l}\text { § } \\
\text { ஸे }\end{array}$ & 出 & $\stackrel{F}{\circ}$ & 둥 \\
\hline 미 & 호 & 嵒 & 导 & 5ั & $\begin{array}{l}\text { gू } \\
\text { 영 }\end{array}$ & ¿ே & $\begin{array}{l}\text { 足 } \\
\text { 잉 }\end{array}$ & $\begin{array}{l}\text { R } \\
\text { 它 }\end{array}$ & $\begin{array}{l}\text { 吕 } \\
\text { 。 }\end{array}$ & $\begin{array}{l}\mathscr{@} \\
\stackrel{0}{0}\end{array}$ & 흥 \\
\hline 可 & ్ㅗ & 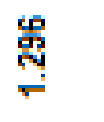 & 吕 & $\underset{\mathrm{N}}{\bar{N}}$ & 导 & $\underset{\text { ळ }}{\stackrel{g}{\circ}}$ & 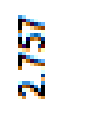 & స్ర్ & 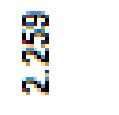 & స్ & 哭 \\
\hline ن & ஜํํ & 品 & 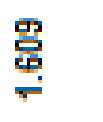 & 尽 & $\begin{array}{l}\text { 品 } \\
\text { N }\end{array}$ & $\underset{ }{\stackrel{N}{*}}$ & 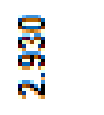 & 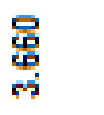 & 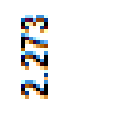 & 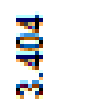 & 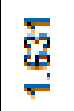 \\
\hline ఫ్వ & 홍 & 电 & స్ర్ & $\begin{array}{l}\text { 今్ } \\
\text { జ్ }\end{array}$ & 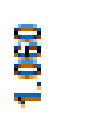 & 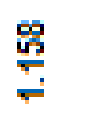 & $\stackrel{\text { 吕 }}{\leftarrow}$ & 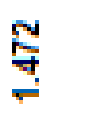 & 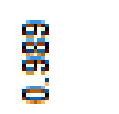 & 울 & స̃ \\
\hline 는 & ஜํํ & $\begin{array}{l}\stackrel{0}{6} \\
\stackrel{6}{0}\end{array}$ & $\begin{array}{l}\text { 吕 } \\
\text { \% }\end{array}$ & 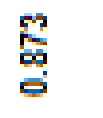 & 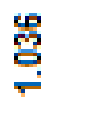 & $\stackrel{5}{\rightleftarrows}$ & 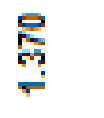 & 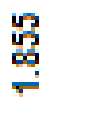 & 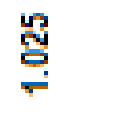 & $\underset{\overbrace{}}{\stackrel{乛}{\sigma}}$ & 岇 \\
\hline অ & స్ & 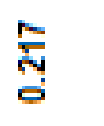 & 总 & 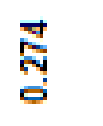 & ஸ્ఝ & స్ స్ & స్ & 氶 & స̃ & 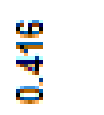 & 둥 \\
\hline a & 유 & ָㅗㅇ & 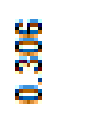 & స్ఞ & 第 & $\begin{array}{l}\text { 怘 } \\
\text { ¿ }\end{array}$ & 율 & 总 & 岂 & 号 & 훙 \\
\hline 可 & ్ㅡ & 昼 & 哿 & 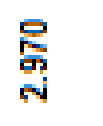 & $\begin{array}{l}\text { 哭 } \\
\text { N }\end{array}$ & 哭 & 吕 & $\begin{array}{c}\text { 令 } \\
\text { N }\end{array}$ & 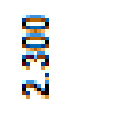 & 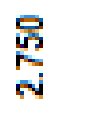 & E \\
\hline $\begin{array}{l}\text { 든 } \\
z\end{array}$ & 유 & 울 & స్ & $\begin{array}{l}\text { 今్ } \\
\text { ㄱ }\end{array}$ & 胥 & 울 & 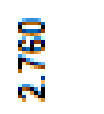 & 品 & $\begin{array}{l}\text { क्g } \\
\text { iv }\end{array}$ & $\begin{array}{l}\text { R్ } \\
\stackrel{6}{N}\end{array}$ & $\frac{n}{5}$ \\
\hline & & 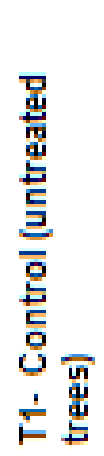 & 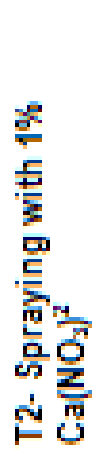 & 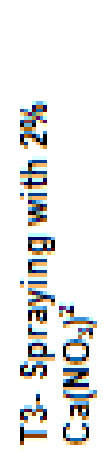 & 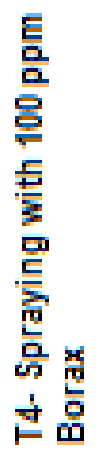 & 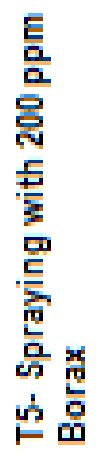 & 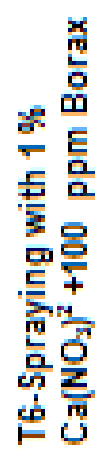 & 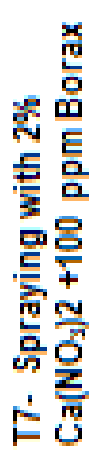 & 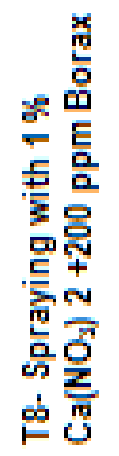 & 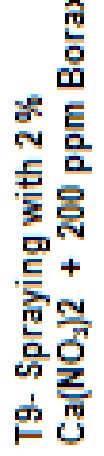 & $\begin{array}{l}\text { 잉 } \\
\text { ○ } \\
\text { 茾 } \\
\text { 品 }\end{array}$ \\
\hline
\end{tabular}


Leaf mineral contents ( $\mathrm{Fe}, \mathrm{Zn}, \mathrm{Mn}$, $\mathrm{Cu}$ and $\mathrm{B}$ )

Results in Table 5 reveal that, in most cases, $\mathrm{Fe}$ and $\mathrm{Zn}$ contents of pear leaves were increased significantly by spraying $2 \% \mathrm{Ca}\left(\mathrm{NO}_{3}\right)^{2}+100$ and $200 \mathrm{ppm}$ borax or $100 \mathrm{ppm}$ boron alone in both seasons. Mn content was enhanced with spraying $1 \% \mathrm{Ca}\left(\mathrm{NO}_{3}\right)^{2}+100 \mathrm{ppm}$ borax or $2 \% \mathrm{Ca}$ $\left(\mathrm{NO}_{3}\right)^{2}+200 \mathrm{ppm}$ boron + in both seasons. Also, $2 \% \mathrm{Ca}\left(\mathrm{NO}_{3}\right)^{2}+200 \mathrm{ppm}$ borax $+1 \% \mathrm{Ca}\left(\mathrm{NO}_{3}\right)^{2}$ or alone gave the highest significant value of $\mathrm{Cu}$ content in both seasons. Whereas, spraying 100 ppm boron $+1 \% \mathrm{Ca}\left(\mathrm{NO}_{3}\right)^{2}$ or $200 \mathrm{ppm}$ boron $+2 \% \mathrm{Ca}\left(\mathrm{NO}_{3}\right)^{2}$ together or $2 \% \mathrm{Ca}$ (NO3)2 alone led to incease leaf $B$ content. In contrast, the lowest significant values of all parameters in Table 5 were noticed with control treatment in both seasons. Similar trend was recorded for $\mathrm{Cu}$ content by foliar application of $2 \% \mathrm{Ca}\left(\mathrm{NO}_{3}\right)^{2}$ in the first season only. The obtained data are in the same trend with the findings of Hanson, 1991, Fry, 2004 and Mosa, et al., (2015).

\section{Fruit mineral contents (N, P, K, Ca and $\mathrm{Mg}$ )}

Results in Table 6 illustrate that the spraying of $2 \% \mathrm{Ca}\left(\mathrm{NO}_{3}\right)^{2}, 100$ or 200 ppm B and $2 \% \mathrm{Ca}\left(\mathrm{NO}_{3}\right)^{2}+100$ ppm B gave the highest significant value of nitrogen content in pear fruit comparable to the other treatments, in both seasons. Fruit $P$ content was improved by foliar spray of $100 \mathrm{ppm} \mathrm{B}$ alone in both seasons. $K$ content in pear fruit was improved significantly with spraying of 200 ppm B compared to the other treatments in both seasons. With regard to fruit calcium and magnesium contents, results show that foliar application of $2 \%$ $\mathrm{Ca}\left(\mathrm{NO}_{3}\right)^{2}$ alone gave the highest significant values of such nutrients of pear fruit in both seasons. While, 200 ppm boron with $2 \% \mathrm{Ca}\left(\mathrm{NO}_{3}\right)^{2}$ led to significant increase of $\mathrm{Mg}$ content only in both ones. Conversely, the lowest significant values of the abovementioned elements were occurred by control treatment in two seasons. The obtained results are in the same trend with the findings of Hanson, 1991 who found that the foliar application of boron was highly effective in improving, nutritional status, yield and quality of pear and apple trees. Also, the recorded data are in harmony with those obtained by Abo El-Enien, (2012), Mosa, et al., (2015) and White and Brodadly, (2003).

\section{$\mathrm{Fe}, \mathrm{Zn}, \mathrm{Mn}, \mathrm{Cu}$ and $\mathrm{B}$ content of pear fruits}

Available data in Table 7 show that single spraying $1 \% \mathrm{Ca}\left(\mathrm{NO}_{3}\right)^{2}$ improved significantly of $\mathrm{Fe}$ and $\mathrm{B}$ contents in pear fruits, while foliar application of boron with the concentration of $100 \mathrm{ppm}$ increased significantly $\mathrm{Zn}$ content in both seasons, respectively. Also, Mn content was increased significantly with foliar application of $200 \mathrm{ppm}$ boron only. Moreover, $2 \% \mathrm{Ca}\left(\mathrm{NO}_{3}\right)^{2}$ with 100 or 200 ppm B enhanced $\mathrm{Cu}$ content in both ones. Alternatively, the lowest significant values of $\mathrm{Fe}$. $\mathrm{Zn}$. Mn, $\mathrm{Cu}$ and $\mathrm{B}$ content were observed with control treatment in both seasons. Similar trend was recorded for $\mathrm{Fe}$ and $\mathrm{Zn}$ content by foliar application of $1 \% \mathrm{Ca}\left(\mathrm{NO}_{3}\right)^{2}+100 \mathrm{ppm} \mathrm{B}$ and $+1 \% \mathrm{Ca}\left(\mathrm{NO}_{3}\right)^{2}+200 \mathrm{ppm} \mathrm{B}$ in both seasons, respectively, in addition, $\mathrm{Cu}$ content under foliar application of $1 \% \mathrm{Ca}$ $\left(\mathrm{NO}_{3}\right)^{2}$ in the first season only. The obtained data are in the same trend with the findings of Hanson, 1991 and Mosa et al.)., 2015. 


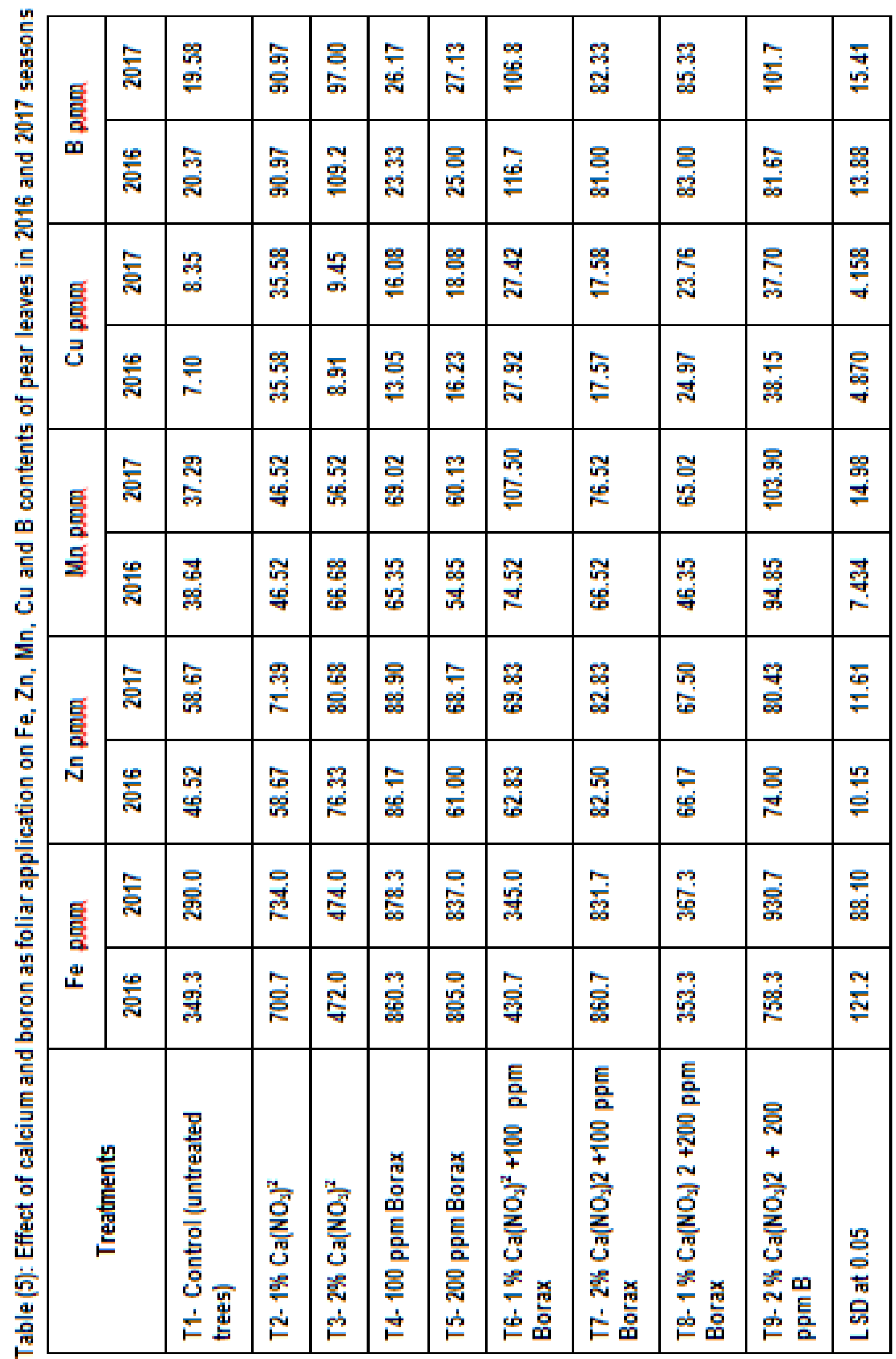


H.M. Abo Ogiela, et al.,

\begin{tabular}{|c|c|c|c|c|c|c|c|c|c|c|}
\hline \multirow{2}{*}{$\begin{array}{l}\text { 모 } \\
\text { 멸 } \\
\text { 몰 }\end{array}$} & 훙 & 훙 & 를 & 용 & $\frac{2}{8}$ & $\begin{array}{l}\text { 물 } \\
\end{array}$ & 응 & $\frac{1}{8}$ & 뭉 & 옹 \\
\hline & 물 & 홍 & 8 & 兽 & 훙 & 뭉 & 홍 & 홍 & 옹 & 号 \\
\hline \multirow{2}{*}{ 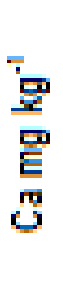 } & 롤 & 总 & 옹 & 号 & 할 & 骂 & 超 & 홍 & 8 & 웅 \\
\hline & 旁 & 驾 & 롱 & 邑 & 롤 & $\mathrm{g}$ & 홍 & 鸪 & 용 & 考 \\
\hline \multirow{2}{*}{ 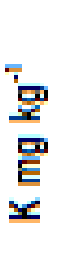 } & 总 & 몽 & $\mathrm{g}$ & $E$ & 5 & 용 & 흥 & E & 点 & 웅 \\
\hline & 㑒 & 孛 & 点 & 홍 & 항 & 寻 & 誉 & 点 & 5 & 영 \\
\hline \multirow{2}{*}{ 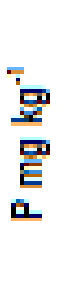 } & 훙 & 总 & 월 & 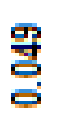 & $\mathrm{g}$ & 몽 & 웡 & 물 & 항 & 웅 \\
\hline & 훌 & 옹 & 롤 & 总 & 롤 & 홍 & 웅 & 骂 & 웅 & 웅 \\
\hline \multirow{2}{*}{$\begin{array}{l}\text { 모 } \\
\text { 몰 } \\
\text { 물 } \\
z\end{array}$} & 훌 & 号 & 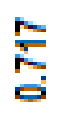 & 点 & 을 & E & 웋 & 웅 & 궁 & 5 \\
\hline & 물 & 吕 & 5 & 总 & $\mathrm{g}$ & 몸 & 옴 & 훙 & 骂 & 奌 \\
\hline & & 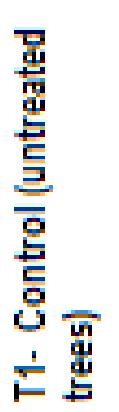 & 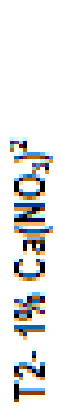 & 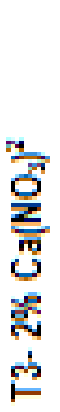 & 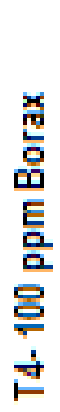 & 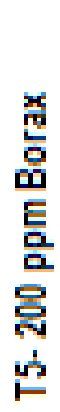 & 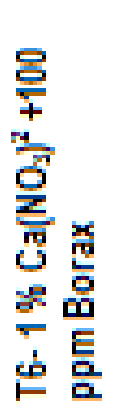 & 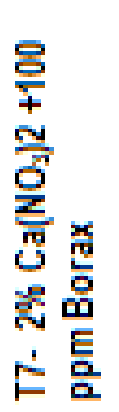 & 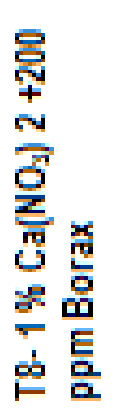 & 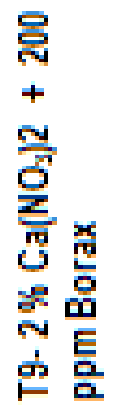 \\
\hline
\end{tabular}




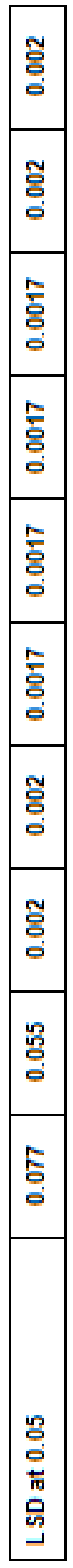

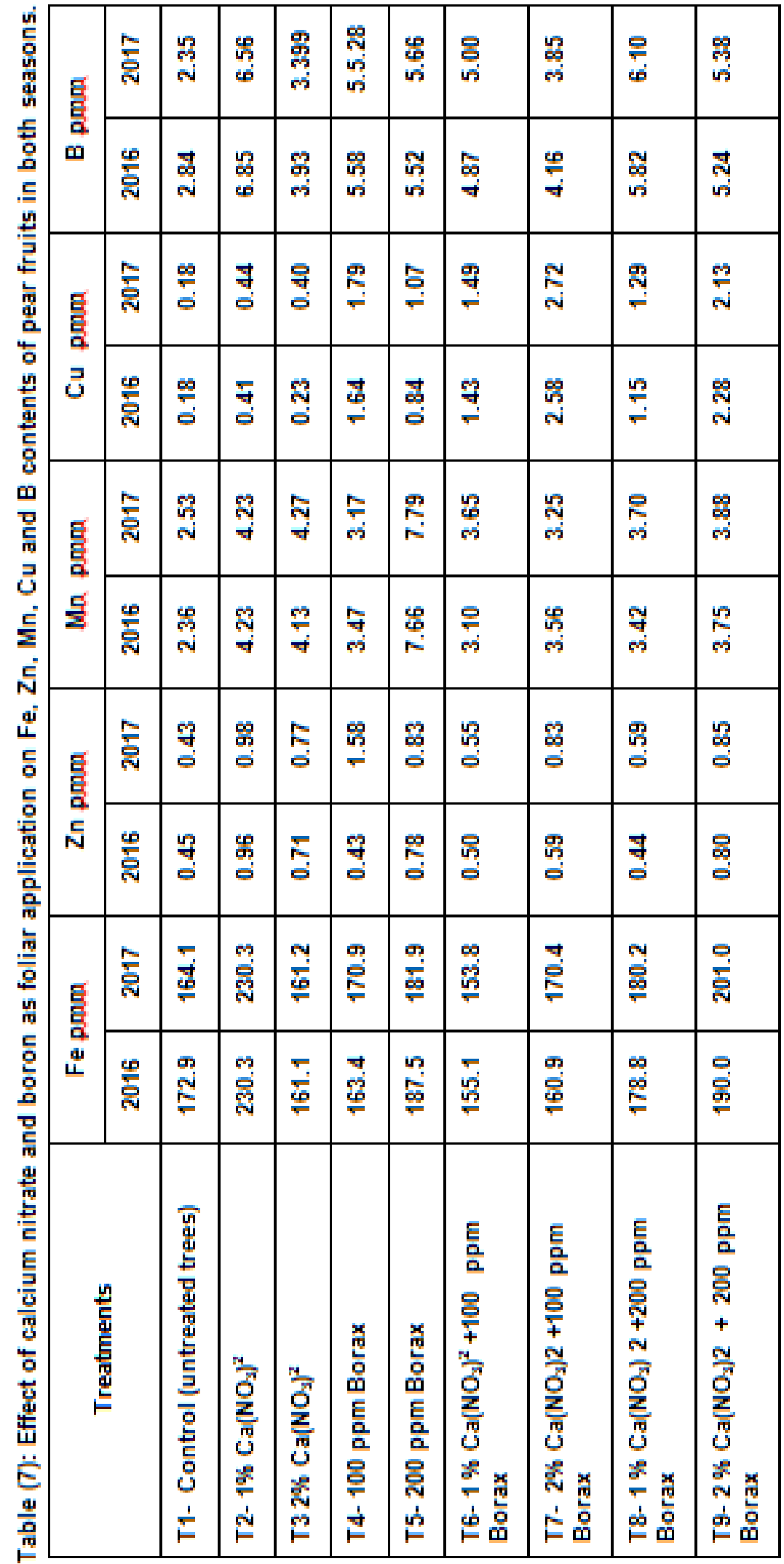




\section{Conclusion}

Based on the results obtained from this study, it is concluded that spraying Le Conte' pear trees with boron and calcium nitrate as individual or in combination had a positive effect on fruit set, yield and fruit quality. However, the best treatment is spraying boron at 200 ppm in combination with calcium nitrate at $2 \%$ since it gave the highest values concerning fruit set, retention, weight and yield, also. fruit physical and chemical characteristics as well as nutritional status of leaves and pear fruits.

\section{REFERENCES}

A.O.A.C. Association of Official Agricultural Chemists (2000). "Official Methods of Analysis" Benjamin Franklin Station. Washington, D.C. USA. P.495-510.

Abdel Hafeez, A.A., A.I. Mohamed, N.M. Taha and S.M.A. Mehaisen (2010). Effect of some sources of potassium and calcium as a foliar spray on fruit quality and storability of Kelsey plums. Egypt. J. Hort.37: 15 1-168.

Abo El-Enien, M.M.S. (2012). Improvement of Washington navel orange fruit quality using water regimes and GA3, potassium and calcium foliar applications. Ph.D. Thesis, Fac. Agric., Kafrelsheikh Univ., Egypt.

Asgharzade, A., G.A. Valizade and M. Babaeian (2012). Effect of Calcium Chloride $(\mathrm{CaCl} 2)$ on some quality characteristic of apple fruits in Shirvan region. Afri. J. Microbiol. Res, 6(9): 2000- 2003.

Casero, T., A. Benavides, J. Puy and I. Recasens (2004). Relationships between leaf and fruit nutrients and fruit quality attributes in Golden Smotthee apples using mu Itivariate regression techniques. J. Plant Nut, 27: 313-324.

Dahajipour, H. M., F. Ghanati and T. Fujiwara (2011). Interaction between boron and aluminum and their effects on phenolic metabolism of Linum usitatissimurn L. roots. Plant Physiol. Biochem.49:1377-1383.

Dermuth, B. and 0. Sundrud (2012). Determination of calcium, magnesium, and potassium in various apple samples using ICP-AES. Concordia College J. Anal. Chern.;3: 19-23.

FAQ. (2011). Food and Agriculture Organization Production Year Book. FAQ, Washington, DC, USA.:6I.

fruit set, yield and fruit quality of cv. Amhat Date Palm. World Journal of Agricultural Sciences 8 (5): 506-515.

Fry, S.C. (2004). Primary cell wall metabolism: tracking the careers of wall polymers in living plant cell. New Phvtol., 161. 641-675.

Goldwin, G.K. (1986). Use of hormone setting sprays with monoculture orchards to give more regular cropping. Acta Hort. 199: 343-48.

Hanson, E.J. (1991). Sour cherry trees respond to foliar boron applications. Hort Science.;26: 1142-1145.

Hassan, H.S.A. (2000). Morphological and Physiological studies on flowering, pollination and fruiting of Picual olive trees. PhD Thesis, Fac. Of Agric., Cairo Univ., Egypt, pp: 111.

Herrera-Rodrlguez, M.B., A. GonzálezFontes, J. Rexach, J.J. CamachoCristóbal, J.M. Maldonado and M.T. Navarro-Gochicoa (2010). Role of boron in vascular plants and response mechanisms to boron stresses. Plant Stress 4 (Special Issue 2):I 15-122.

Kazermi, M. (2014). Influence of foliar application of iron, calcium and zinc sulfate on vegetative growth and reproductive characteristics of strawberry cv. pajaro'. Trakia J. Sci. 1:21-26.

Khalifa, R. Kh. M., Q.M. Hafez and H. AbdElKhair (2009). Influence of Foliar spraying with boron and calcium on productivity, fruit quality, nutritional status and controlling of blossom end rot disease of Anna apple trees. World Journal of Agricultural Sciences 5:237-249. 
Khayyat, M., E. Tafazoli, S. Eshghi and S. Rajaee (2007). Effect of nitrogen, boron, potassium and zinc sprays on yield and fruit quality of date palm. American-Eurasian Journal of Agricultural and Environmental Science, 2:289-296.

Magness, J. R. and C. F. Taylor (1925). An improved type of pressure tester for the determination of fruit maturity. U.S. Dept. Agric. Circ. PP. 350-358.

Mengel, K. and E.A. Kirkby (2001). Principles of Plant Nutrition. 5 Rev. Ed., Kluwer Academic Publisher (United States). ISBN- 10: 1402000081.

Merwad, M.A., R.A. Eisa and M.M.S. Saleh (2016). The beneficial effect of NAA, $\mathrm{Zn}, \mathrm{Ca}$ and $\mathrm{B}$ on fruiting, yield and fruit quality of Alphonso mango trees. Int.J. ChernTech Res.,9: 147-157.

Mishra, N., A. Dubey, R. Mishra and N. Bank (2010). Study on antioxidant activity of common Llry fruits. Food and Chemical Toxicology 48:33 163320.

Moalermi, R., M. Aghdasi and F. Ghanati (2012). Induction of phenolic compounds is affected by boron supply in marshmallow (Althaea ofticinalis L.) cells. Progress in Biological Sciences 2:68-75.

Montanaro, G., B. Dichio, C. Xiloyannis and G. Celano (2006). Lightinfluences transpiration and calcium accumulation in fruit of kiwifruit plants (Actinidia deliciosa var. deliciosa). Plant Sci., 170, 520-527.

Mosa, W. F. A., Nagwa A. Abd ELMegeed, M. A. M. Aly and Lidia S. Paszt (2015). The Influence of NAA, GA3 and Calcium Nitrate on Growth, Yield and Fruit Quality of "Le Conte" Pear Trees. American Journal of Experimental Agriculture 9(4): 1-9.

Polevoiy, V.V. (1989). Calcium-related physiological disorders of plants. Ann. Rev. Phytopathol, 17: 97-122.

Qin, X. (1996). Foliar spray of $B, Z n$ and $\mathrm{Mg}$ and their effects on fruit production and quality of Jincheng orange Citrus sinensis. Journal of
South West Agricultural Univ., 18(1): 40-45.

Rizzi, E. and A. Abruzzese (1990). Effects of calcium treatment on some biochemical indexes during the developing of apple fruit, Hort. Abst., 60 : 4966- 4973.

Ryan, J., S. Garabet, K. Harmsen and A. Rashid (1996). A soil and plant Analysis Manual Adapted for the West Asia and North Africa Region. ICARDA, Aleppo, Syria. I40pp.

Saadati, S., N. Moallemi, S.M.H. Mortazavi and S.M. Seyyednejad (2013). Effects of zinc and boron foliar application on soluble carbohydrate and oil contents of three olive cultivars during fruit ripening. Scientia Hort. 164: 30- 34.

Sarrwy, S.M.A., E.G. Gadalla and E.A.M. Mostafa (2012). Effect of Calcium Nitrate and Boric Acid Sprays on

Saure, M.C. (2005). Chemical translocation to fleshy fruit: its mechanism and endogenous control. Sci. Hort.. 105,65-89.

Snedecor, G. W. and G. W. Cochran (1990). Statistical Methods. $7^{\text {th }}$ Ed. The lowa State Univ. Press Ames. Ioa. USA.

Stino, R. G., Sahar M. Abd EI-Wahab, S.A. Hobashy and R.A. Kelani (2011). Productivity and fruit quality of three mango cultivars in relation to foliar sprays of calcium, zinc, boron or potassium. Journal of Horticultural Science \& Ornamental plants, 3: 91 98.

Stückrath, R., R. Quevedo, L. de la Fuente, A. Hernández and V. Sepâlveda (2008). Effect of foliar application of calcium on the quality of blueberry fruits. J. Plant Nutr. 31:1299-1312.

Vogel, A. (1968). A Text Book of Quantitive Inorganic Analsis. Longmans, New York, pp. 1216.

Westwood, M. N. (1978). Temperate Zone Pomulogy W. H. Freeman and Company. San Francisco. 
White, P.J. and M.R. Broadly (2003).

Calcium in plants. Ann. Bot.. 92. 487511.
Wimmer, M and T. Eichert (2013). Review: Mechanisms for boron deficiencymediated changes in plant llater relations. Plant Sd. 203-204:25-32.

تأثير الرش الكالسيوم والبورون علي انتاجية اشجار الكمثري صنف ليكونت

هشام محمد عبد الحميد ابو عجيله(')، شعبان محمد حسين(')،

عصام الدين عبد العزيز محمد عثمان(؟)، عبد الحميد الغضبان عبد اللطيف شريف(؟)

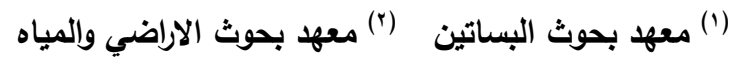
مركز البحوث الزراعيه - الجيزه- مصر بلهر

الملخص العربي

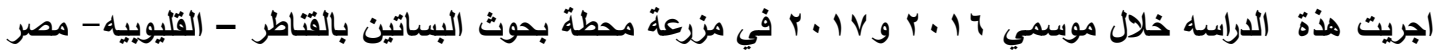
بهاف دراسة استجابة اثجار الكمثري ليكونت لمعاملات الرش الكالسيوم والبورون في 9 ف معاملات للرش علي الاثجار

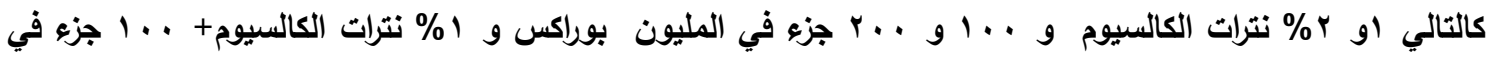

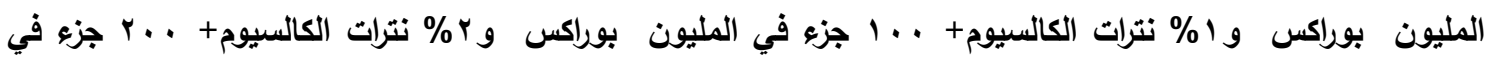

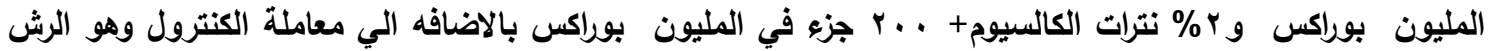
بالماء فقط على المحصول وجودة الثمار. ويمكن تلخيص النتائج المتحصل عليها فيما يلي:-

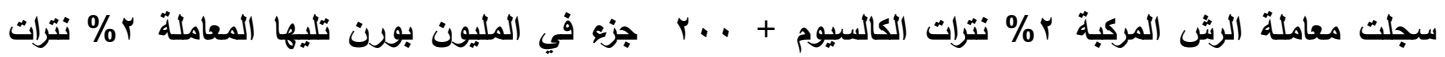
الكالسيوم + + . 1 جزء في المليون افضل النتائج حيث ادت الي زياده معنويه في نسبة عقد الثمار والمحصول وجودة الثمار خاصة صلابة الثمار ومحتواها من الماد الصلبة الذائبة ومحتوي الاولق من العناصر وجودة الثمار مقارنه بالمعاملات الاخري والكنترول خلال موسمي الداسه . 
أسماء السادة المحكمين

أ.د/ جهاد بشرى يوسف ميخائيل مركز البحوث الزراعية - الجيزة

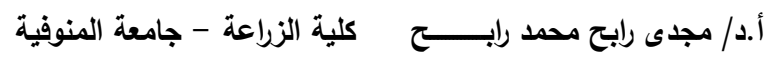


